\title{
The Impact of Microfinance on Maize Farmers in Nkoranza (Brong Ahafo Region of Ghana)
}

\author{
Samuel Adams \\ Ghana Institute of Management and Public Administration \\ P.O. Box AH 50, Achimota- Accra \\ E-mail: sadamss2000@yahoo.com
}

Theresa A. Bartholomew

Saint Theresa’s Hospital

Nkoranza, Brong Ahafo Region

\begin{abstract}
Advocates of microfinance argue that Microfinance is a powerful to alleviate poverty. In recent times, however, many studies do suggest that the reality promise of microfinance may be less attractive the promise. This study examined the impact of microfinance from the perspectives of maize farmers in Nkoranza in the Brong Ahafo Region of Ghana. The findings of the study based on a survey of 100 participants in the microfinance program suggest that the impact of microfinance on both social and economic wellbeing is marginal. The key issue identified by most of the recipients is lack of entrepreneurial skills and market for their produce. The key recommendation from the study is the need improve infrastructure and establish linkages between the farm and non-farm sectors of the rural economy.
\end{abstract}

Keywords: Microfinance, Maize farmers, Ghana, Economic well being, Social well being 


\section{Introduction}

In recent times, Ghana has emerged as one of the leading nations in Sub-Saharan Africa that is on course to achieve the Millennium Development Goals before the 2015 deadline. It is also managed peaceful political transition in 2008 and established a strong political and policy environment for economic progress and poverty reduction IFAD (2009). The overall poverty level in Ghana reduced from 56 percent in 1992 to 28 percent in 2006 (World Bank, 2006).

Though Ghana's economy has grown at an average annual rate of $4.5 \%$ over the past two decades, the agricultural sector still dominates and contributes about 34\% and employs nearly $55 \%$ of the labor force (World FactBook, 2008). Low productivity and poorly functioning markets for agricultural outputs are among the causes of poverty as indicated in the government's poverty reduction strategy paper. Small scale farmers rely on rudimentary methods and technology and they have limited skills and inputs such as improved seeds that would increase yields. Poverty is deepest among food crop farmers, who are mainly traditional small scale producers. About six out of ten small-scale farmers are poor and many of them are women (IFAD, 2009).

In the last few decades, the government of Ghana has implemented many programmes to reduce poverty, including the Livelihood Employment against Poverty (LEAP), Programme of Action to Mitigate the Social Cost of Adjustment (PAMSCAD) and Microfinance and Small Loan Scheme (MASLOC). Of the various tools used in poverty reduction, microfinance has become the most popular in recent times across developing countries as a whole. This is because access to credit has been recognized as one of the many strategies that could be used to combat poverty.

From an obscure experiment in Bangladesh 30 years ago, microfinance has become a worldwide movement as a development activity, a way of helping poor people out of poverty (Ditcher, 2006). In light of its prominent role in development economics, Buckley (1997) described it as the newest darling of the donor community, while Karnani (2007) portrays it as the newest silver bullet for alleviating poverty and Greer (2008) and Gupta and Aubuchon (2008) claim that microfinance shines as a proven way to improve the lives of the poor. The Nobel Prize committee for 2006 identified microfinance as a liberating force and an important instrument in fighting poverty. Accordingly, by the late 1990s, microfinance had become the darling boy of most donor agencies and subsequently received a chunk of the budget (Buckley, 1997). This was also boosted by the UN's declaration of 1997-2006 as a decade for the eradication of poverty.

Other studies, however, suggest that the impact of microfinance has been over advertised or hyped (United Nations Capital Development Fund [UNCDF], 1999; Ditcher, 2006; Karnani, 2009). Sachs (2009) also argues that the conditions in Africa do not allow microfinance to have its full effect. He claims that the terrible conditions in Africa (disease, poverty, and poor governance environment) would have to be fixed first before microfinance could be beneficial. Because of these ambiguous results, many authors point to the use of citizens' perception (Durant and Legge, 2002 and Battaglio and Legge, 2009) to examine the impact of 
microfinance as this study seeks to do. The findings of the study will help to provide policy direction as to the benefits or otherwise of microfinance and subsequently future directions as to what could be done to maximize the expected benefits from microfinance.

The rest of the paper is structured as follows: section two gives a background of microfinance in Ghana and is followed by discussion of the theoretical and empirical literature on the microfinance-poverty or well-being relationship. The research methodology is then presented after which the findings of the study are presented are discussed. Finally, we give the policy implications and concluding remarks

\section{Literature review}

This section presents a background of microfinance in Ghana, after which we discuss the theoretical and empirical studies on the microfinance-poverty relationship.

\section{Background of Microfinance in Ghana}

Microfinance activities in Ghana as in other developing countries can be grouped into three areas such as financial services (loans, deposits, leasing etc); non-financial services (literacy classes, nutrition, health, etc); and business development or advisory services (International Year of Microcredit [IYMC], 2005). Microfinance services in the financial sector have spread all over the nation (Ghana) to serve the needs of the poor and the community as a whole.

Nkoranza has many institutions that seek the welfare of the community through the provision of microfinance services, including traditional banks (Commercial Bank, Agricultural Development Bank) and rural banks (Kwabre Rural Bank) and informal lenders (Private Money Lenders). Informally, moneylenders in the district also pre-finance many economic to social issues like funerals. However, it is worth noting that it is easier for people to obtain loans from rural banks to organize funerals than for farming activities due to lack of collateral. The expected donations from those attending the funerals provide a form of security to the money lender. Arun and Steiner (2008) and de Witte (2003), for example, report that informal insurance mechanisms such as funerals and naming ceremonies are very important in Ghana.

Microfinance services have been useful to the development of food crops (maize) and export crops (pineapple) since 1992 in the district. In recent times, the Ministry of Food and Agriculture has disbursed more than 200 billion Cedis through ADB to farmers' groups in Nkoranza and nearby districts to boost food crop production (GNA, 2005). The project supported the cultivation of maize, cowpeas, sorghum, groundnut and Soya beans and a number of farmers received assistance in the form of agricultural inputs and credit facilities to enhance their activities.

\section{Theoretical and Empirical Review}

Proponents of microfinance argue that small loans to poor people could serve as a powerful tool for alleviating poverty (Khan and Rahaman, 2007). This is consistent with the UNCDF's (2009) claim that microcredit for farmers provides a potent tool for expanding economic opportunities and reducing the vulnerabilities of the poor. Asiama and Osei (2007) have noted 
that this is possible because microfinance helps the poor to meet their basic needs and therefore and improve household income. Similarly, Khan and Rahaman (2007), Robinson (2001), Otero (1999) and Wehrell et al. (2002) arguing from a sociological perspective asserted that access to credit provides the poor with productive capital that helps to build up their sense of dignity, autonomy, and self-confidence, and hence are motivated to become participants in the rural economy. Likewise, Pronyk et al. (2007) argue that microcredit presents the poor with income, food, shelter, education and health and can therefore have immediate and long term consequences.

Gender activists also argue in favour of microfinance as a means of empowerment by supporting women's economic participation. Boyle (2009) claims that by supporting women's economic participation, microfinance helps to improve household well-being. Littlefield (2005) reports that the opportunities created by credit availability helps a lot of poor people to invest in their own businesses, educate their children, improve their healthcare and promote their overall well-being. This is supported by a study by Karlan and Zinman (2006) in South Africa where recipients of microcredit were shown to be better off than non-beneficiaries. In another study by Khan and Rahaman (2007) in the Chittagong district in Bangladesh, recipients of microfinance facilities were reported to improve their livelihoods and moved out of poverty. More importantly, Khan and Rahaman (2007) reported that microfinance recipients had empowered themselves and become very active participants in the economy. Further, using a regression model to examine the impact of microfinance, Priya (2006) found that there is significant positive relationship between credit recipients and income; the findings suggest that program participation led to a $10 \%$ increase in income. However, the UNCDF (2009) report suggests that though microcredit may be helpful in reducing poverty, it is never a panacea and that it is only one of such tools to reduce poverty or the vulnerabilities of the poor. Buckley (1997) and Rogaly (1996) have also noted that microfinance may not always be the best tool to help the poorest of the poor. A similar argument is made by Hashemi and Rosenberg (2006) who claim that microfinance does not reach the poorest in the community.

Roodman (2009) asserts that microcredit might actually leave people worse off, jus as credit cards and mortgages have made people poorer in developed countries. Referring to the over-advertised benefits of microfinance, Ditcher (2006) claims that while the promise of microcredit is irresistible, the hoped for poverty reduction impact of microcredit remains elusive. Karnani (2007) made a similar statement in his critique of microfinance programs and argued that though microcredit yields some non-economic benefits, it does not significantly alleviate poverty and that the promise of microfinance is less attractive than the reality. Karmani (2007) explained that the best way to alleviate poverty is to create jobs and increase worker productivity but not through microcredit. This is because poor borrowers tend to take out conservative loans that protect their subsistence, and rarely invest in new technology, fixed capital or the hiring of labor.

Further, Sachs (2009) claims that microfinance may not be appropriate in every situation and advices against one size fits all strategy in the use of microfinance in poverty alleviation. Sachs explained that the poor governance infrastructure, dispersed populations in the rural 
areas might limit the potential benefits of microfinance in Africa. In these cases, grants, infrastructure improvements or education and training programmes could be more effective. Empirically, Buckley (1997) studied micro enterprises in three African countries (Kenya, Malawi, and Ghana), and questions whether the extensive donor interest in microenterprise finance really addresses the problem of micro-entrepreneurship or just offers a quick fix to the problem. The study's findings suggest that the fundamental problem is lack of infrastructure rather than the injection of capital. On the other hand, Chemin (2008) using a matching strategy to examine the impact of microfinance in Bangladesh reported a positive, but lower than previously thought, effect on expenditure per capita and school enrollment for boys and girls. In another study to examine the impact of microfinance on rural farmers in Malawi, Aguilar (2006) reported that farmers who borrow from microfinance institutions were no better off than those who did not borrow. Like Aguilar (2006), Ausburg (2008) argues that there is the need for a plus component (training in financial management, marketing and managerial skills and market development) for microfinance to succeed.

The studies reviewed above indicate that the promised benefits of microfinance are not always realized and that many other factors including client characteristics, microfinance structure and functional arrangements may mediate the impact of microfinance. Thus, the effect of microfinance is context specific. Consequently, this study contributes to the literature by examining the impact of microfinance on maize farmers in Nkoranza in the Brong Ahafo Region of Ghana. This is basically a descriptive study that focuses specifically on the experiences of the beneficiaries of microcredit. Further, understanding the factors that drive stakeholder perceptions may yield information that can be strategically used to improve those attitudes. Accordingly, we are not seeking to make a generalization about the impact of microfinance but more specifically to examine how microfinance has impacted on the lives of maize farmers in the Nkoranza District of the Brong Ahafo Region in Ghana.

\section{Research Methodology}

Both primary and secondary data were collected to examine the impact of microfinance on maize farmers in Nkoranza. Primary data was obtained from interviews and focus group discussions and secondary data obtained from Agricultural Development Bank (ADB), the managers of the Ghana government's Food Crop Development Project (FCDP). It has to be mentioned that the district has both formal an informal financial institutions (Ghana Commercial Bank Limited and Agricultural Development Bank [ADB], Fiagya Rural Bank and Kwabre Rural Bank ADB was selected because of the availability of data and the opportunity to get recipients to partake in the study.

Overall, 100 beneficiaries of the FCDP were selected focusing specifically on the maize farmers since the project was meant for food crops. Initially, the idea was to sample within a $10 \mathrm{~km}$ radius, but this did not give enough recipients, and therefore we later decided to look for recipients within a $20 \mathrm{~km}$ radius. Five communities in the South and five communities in the North and in each community the beneficiaries of the FCDP had the membership of ten to fifteen people. The farm size ranges from half an acre to two-hectares. Assistance was given in the form of agricultural inputs and partly money. The Government of Ghana, The Ministry 
of Food and Agriculture and ADB collaborated to implement the project in response to food insecurity in the country at the time (2001-2007). Ghana government disbursed the fund through ADB while training of beneficiaries on best practices and technological use was handled by District Agricultural Development Unit (DADU) in Nkoranza.

All the respondents had savings account at $\mathrm{ADB}$ as one of the criteria to qualify to join the project. Initially, the clients were not cooperative because they had a previous experience where beneficiaries within the area had military men come to harass them to pay off government loans. Accordingly, prior to the administration of the questionnaire, we had meetings with the community or opinion leaders to explain the purpose of the project-which is to understand how the microfinance was impacting on their lives and how best to improve the programme. This approach helped to get all the recipients selected to fill the questionnaire, thus a $100 \%$ response rate.

The questionnaire was made up of both structured and unstructured questions. Interview with credit providers and focused group discussion with the beneficiaries were conducted to enable them confirm what had been answered on the questionnaire but more importantly to allow them express their feelings and opinions in an unrestrained manner. The survey questionnaire sought to gather information on the demographic and occupational issues, economic activities, consumption patterns, and social wellbeing.

\section{Results and discussion}

The results of the study are discussed under three main headings, including demography, economic and social well-being.

\section{Demographic Information of the Respondents}

The demographic information we examine here include age, gender, and the number of children of recipients.

\section{Age Distribution of Respondents}

All the 100 beneficiaries responded to the question on age and the responses indicate that most of the respondents (35\%) are in the 41 to 50 years bracket with another 31\% in 51-60 range, and $24 \%$ above 60 years of age (Table 1). Interestingly, only ten recipients (10\%) are below the age of 40.years. This suggests that agriculture is not so attractive to the youth of the community, who prefer to be farm laborers (for quick money) or travel out of Nkoranza to look for non-farm jobs. Our focus group discussions also revealed that financial institutions are cautious in giving credit to the young people because of the quest to travel outside the locality. Farming is therefore left in the hands of aged who embark on subsistence farming that contributes to the low food production in the area.

\section{Gender}

The beneficiaries were made up 65 males and 33 females. Though equal opportunity was given to both men and women to apply for the microcredit facility, the ratio of men to women is about 2:1. This finding is consistent with the view that men are more likely to 
Table 1. Age Distribution of Respondents

\begin{tabular}{|l|l|l|}
\hline Years & Frequency & Percentage \\
\hline $30-40$ & 10 & 10 \\
\hline $41-50$ & 35 & 35 \\
\hline $51-60$ & 31 & 31 \\
\hline $61-70$ & 17 & 17 \\
\hline 71 and above & 7 & 7 \\
\hline
\end{tabular}

go for credit than women. Focus Group discussions with the beneficiaries also revealed that some of the female beneficiaries sought permission from their husbands before they could access the credit. The respondents indicated that in a few cases the husbands refuse or may go for the loan on behalf of the wife. Goetz and Gupta (1996) make a similar argument that it is mostly the men of the household and not the women who actually exercise control the borrowing.

\section{Number of Children of the Respondents}

Most of the respondents had between four - six children (52\%), while only $13 \%$ had less than four children and $36 \%$ had over six children and $10 \%$ of the respondents had more than 10 children. Thus, most of the beneficiaries of the microfinance facility had a large family size hoping that the children would grow to help with the farming.

Table 2. Number of Children of the Respondents

\begin{tabular}{|l|l|l|}
\hline Number of Children & Frequency & Percentage (\%) \\
\hline $0-3$ & 13 & 13 \\
\hline $4-6$ & 52 & 52 \\
\hline $7-9$ & 25 & 25 \\
\hline $10+$ & 10 & 10 \\
\hline Total & 100 & 100 \\
\hline
\end{tabular}

\section{Economic Well-Being of the Respondents}

This segment studies the impact of microfinance on the economic wellbeing of respondents. It presents their economic activities, their major source of income and sustenance followed by conditions for receiving the credit, its payment and impact on their income and savings. All the respondents indicated that they had a maize farm (a requirement to receive the credit), though they were also engaged in the production of other food crops (Water Melon, livestock, groundnut, and yam) or trading activity. As pertains in most rural communities in Ghana, the farmers are not full time mono croppers (Table 3). The farmers usually spread their loans on these activities as revealed during the focus group discussion. This supports the substitution argument of Karlan and Zinman (2009) that indicates that microcredit works broadly through risk management and investment at the household level rather than directly through the targeted businesses. It is possible that microfinance is helping recipients to diversify their livelihoods in terms of income generation. As noted by Murdoch (1998), access to credit aids 
the diversification of labor supply across seasons, which in turn is associated with a reduction in the variability of consumption across seasons?

When asked about repayment of the loan, 69 out of 90 people who responded (77\%) indicated that they could not pay off their loans. The reasons given for this include, bad weather, late supply of inputs, small size of loan, lack of market access or demand for products, loss of relative, and low production were given. It is interesting to note that of the $23 \%$ respondents who were able to pay off their loans, this was not done through only maize production. The respondents explained that some of the money used came from profits from other food crops and activities and Susu contributions (savings). Focus group discussions revealed that fear of being prosecuted was a key driver that forced them to pay their debt. Consequently, there are times when they had to sell off some property or asset to pay off the loan. This finding supports Kiiru's (2007) claim that poor households

Table 3. Economic Activities of Respondents

\begin{tabular}{|l|l|}
\hline Economic activities & Frequency \\
\hline Maize & 100 \\
\hline Watermelon & 3 \\
\hline Livestock rearing & 29 \\
\hline Other crops and non- farm activities & 68 \\
\hline
\end{tabular}

deplete their livelihood or assets in the course of loan repayment since their income generating activities do not yielding enough profits

Subsequently, when the recipients were asked about the direct impact of the microfinance on their income, 38 out of 71 (54\%) responses indicated that the credit did have a positive effect on their income. Most of them, however, attributed the improvement in income to the other economic activities (non-farm) that they engaged in. Many of those who did not see an appreciable increase in income (46\%) blamed the low price of maize on the market and high cost of living as key factors. The recipients asked for more time to be able to repay their loans. This means that not only is the non-farm sector critical but also that microfinance beneficiaries need to be involved in the programme for some time to experience its intended effects (Cannon and Smith, 2002; Onchan, 2004).

\section{Social Well-being Of The Respondents.}

This section takes into account the education of beneficiaries' children, health care of the respondents, housing, clothing, community obligations and the general perception of the facility. With respect to education, 63 out of 90 respondents (70\%) said they could provide educational materials for their children and could send them to school while four $(4.4 \%)$ could not provide or send their children to school and 23 (26\%) reported that their situation had not changed after accessing the credit facility. The responses on health related issues are not very different from that of education. While $43 \%$ could access health care facilities before the credit facility, 51\% reported that they could access health care services after receiving the credit. The respondents did indicate that the National Health Insurance Scheme also helped to improve access to health care services. 
On housing, more than half (74\%) reported that that they have not been able to build new rooms or houses or rehabilitate their houses. The other $26 \%$ people indicated that they used their surplus income to improve their houses rather than investing in direct farming activity. On the question of whether receiving credit has helped to improve the ability to provide clothing for their families, 34 out of 94 respondents indicated that they could provide clothing for their children all year round, while 51 could provide clothing only during Christmas and nine could provide clothing twice a year. It is important to note though that most of the participants do buy used or second hand clothing (focus group discussions).

Finally, the respondents were asked whether the microfinance programme had any impact on their social life in terms of community participation. Many more people responded (99\%) to this question than any other social well-being question. A key issue in the rural community is the payment of community levies, which helps to establish their sense of belonging. All the respondents were able to fulfill this social obligation with the exception of one. Overall, when asked whether receiving the credit has impacted their lives, 52 respondents said that the credit had a positive impact on their lives, while 14 reported that the credit did not have any impact on their lives and 34 indicated that the credit has made their lives worse. The positive impacts mentioned range from tangible to intangible benefits especially the education they received before and during the project, which helped to improve their productivity and therefore profitability. Those who experienced losses attributed this to lack of a ready market or the inability to sell their produce. Another issue mentioned for the losses, include the loss of a relative. When there is death of family member, some of the farmers do spend the money on funerals, hoping to get donations from sympathizers during the funeral ceremony. When this expectation is not met, the farmers become more impoverished.

\section{Policy Implications and Conclusions}

This is a descriptive that sought to examine the impact of microfinance on maize farmers in Nkoranza in the Brong Ahafo Region of Ghana from the perspectives of the beneficiaries. The findings of the study suggest that Microfinance had a marginal effect on both the economic and social wellbeing of the recipients of the credit facility. The implications of the findings of the study are discussed next First, credit alone cannot serve the farmers and take them out of poverty. As Parker and Pearce (2001) have noted, it is only one of many elements on a menu of possible interventions to generate income and possibly alleviate poverty. In the case of Africa in particular, Kiiru (2007) asserts that there are more important constraints that face the small agricultural households such as individual product prices, land tenure, technology, and market access. These problems place a lot of responsibility on government to create the enabling environment as well as the framework conducive not only for rural finance but also in market development. Sachs (2009), for example, claims that microfinance can play a huge role in alleviating poverty if it helps to find ways through the market to get new opportunities to earn income by the investments in both farm ad nonfarm activities. This view is consistent with the findings of the study which indicate that lack of market for products contributed to the inability of most of the recipients to pay off their debt. 
A second issue which is directly related to the first is the problem of infrastructure. The discussion shows that not only is microfinance not enough in alleviating poverty but that it cannot be a substitute for jobs or markets that are not available or inaccessible. Buckley (1997) has argued that the extensive donor interest in microfinance only offers the illusion of a quick fix and suggests that the problem is the lack of infrastructure rather than just injecting capital. Kimenye (2002) observed that poor road network in most rural areas increase transaction costs and introduce high risks of failing to deliver supplies and materials on time. Accordingly, Parker and Pierce (2001) have argued that in most poor rural communities, investments in infrastructure might be preferred to microfinance, because the factors needed for the microfinance program to be sustainable are absent.

Apart from the physical infrastructure, it is also important for the governance infrastructure to be developed in terms of promoting pro poor policies and possibly a comprehensive strategy that seeks to optimize the use of resources in identifying the best option in reducing poverty including grants, employment programmes, and other non-financial services (literacy classes, and training programmes, community development, market based business development services). Karnani (2007), for example, has argued that the poor needs employment or jobs and not micro credit because not all of the poor can be micro entrepreneurs. Marcus et al. (1999) asserts that where markets are constrained by low population density and limited purchasing power, training and technological development may have a greater impact than microfinance.

Finally, since all the recipients have other jobs apart from maize production, it means that the rural non-farm sector needs to be developed. Onchan (2004) has stated that the rural non-farm sector should be seen as supplementary to agricultural development, and consequently, needs to be supported effectively to reduce poverty in most rural African communities. The findings and the implications discussed above provide some directions for future research. First, future research should examine the impact of microfinance on recipients over time, since some studies suggest that it takes time for microfinance to have an effect on livelihoods of the poor. For example, Sulaiman and Matin (2009) found that microfinance had an effect on recipients only after the third cycle of borrowing. Further, there is the need to identify which particular non-farm activities are able to generate the most benefits to the rural economy. Evidently, since the study is based on the perceptions of the recipients of microfinance in Nkoranza, we cannot generalize the findings of this study to other settings. Accordingly, more bottom up studies need to be done to enhance our understanding of the challenges and impact of microfinance and how best to improve the delivery process. Additionally, there is the need to examine how, when, and what type of linkages between the non-farm and farm sectors are needed to give the desired effect on productivity. The way forward then, is how government, the private sector and civil society organizations (including NGO's) can work together to ensure the success of microfinance and other tools of poverty reduction.

\section{References}

Aguilar, V. G. (2006). Is Micro-finance reaching the Poor? An Overview of Poverty Targeting 
Methods. www.globalnet.org (accessed on 01/08/09)

Arun, T. G. and Steiner, S. (2008) Micro insurance in the context of Social Protection. BWPI Working Paper 55. The University of Manchester Brooks

Asiama, J.P. and Osei, V. (2007). Micro finance in Ghana: An Overview, Research Department Working Paper Bank Of Ghana 07/01. Accra.

Augsburg, B. (2008) Microfinance Plus - Impact of the 'plus' on customers' income in Rural University Maastricht, the Netherlands

Boyle, G. (2009). Be the Change: Empowering Women Through Microfinance. http://www.brazencareerist.com (Accessed on 25/11/09).

Buckley, G. (1997). Microfinance in Africa? Is it Either the Problem or the Solution? World Development, 25(7): 1081-1091.

Chemin, M. (2008). The Benefits of Microfinance from Bangladesh. Journal of Development Studies, 44(4): 463-484

Cannon, T. and Smith, D. (2002). Rural Non farm Economy Project: Uganda Fieldwork

Case Study Synthesis Report. Natural Resource Institute (NRI) Report No. 2701. Kent -UK

De Witte, M. (2003) Money and Death: Funeral Business in Asante, Ghana. Africa, Vol. 73.

Dichter, T. W. (2006) "Hype and Hope: The Worrisome State of the Microcredit. http://conservationfinance.wordpress.com (Accessed on 30/08/09)

Ghana News Agency (2005) Farmers receive 200 billion cedis support for food crop Production. http://www.modernghana.com (accessed on 3/3/09)

Goetz, A. and Gupta, S. (1996). Who Takes the Credit? Gender, Power, and Control over

Loan Use in Rural Credit programs in Bangladesh. World Development, 24(1): 45-63.

Greer, P. (2008). Hitting its Mark: Microfinance and the Alleviation of Poverty.

Gupta, S. and Aubuchon, C. (2008). The Microfinance Revolution: An Overview. Federal Reserve Bank of St. Louis Review, 90(1), 9- 30.

Hashemi, S .and R Rosenberg, R. (2006). Does microfinance reach the poorest? Graduating the Poorest Into Microfinance: Linking Safety Nets and Financial Services. CGAP focus Note. No.34. Washington, DC USA.

International Year of Microcredit (2005) Governance Issues in Microfinance.PRISMS USAID.

Karnani, A. (2007). Microfinance Misses its Mark. Stanford Social Innovation Review Summer 2007.

Kimenye, L.N. (2002). Promoting farm/non farm linkage: A Case study of French bean Processing in Kenya. in Davis et al. (2002). Promoting Non Farm Linkages for Rural 
Development: Case Studies from Africa and Latin America. Food and Agriculture Organization of the United Nations: Rome

Kiiru, J. (2007). Microfinance, Entrepreneurship and Rural Development: Empirical Evidence from Makueni District, Kenya. http://www.csae.ox.ac.uk/conferences/2007. (Accessed on 26/11/09).

Khan, M. A. and Rahaman, M.A. (2007). Impacts of Microfinance on Living Standards,

Empowerment, and Poverty Alleviation and Poor People: A Case Study on Microfinance in the Chittagong District of Bangladesh. http://www.essays.se. (Accessed on 24/11/09)

International Fund for Agricultural Development [IFAD] (2009).Enabling Poor People Overcoming Poverty in Ghana. Http://www.ifad.org. (Accessed on 28/11/09).

Littlefield, E. (2005). Microfinance - Where We Are Now and Where We Are Headed,” Microfinance speech given at the International Year of Microcredit and Georgetown University Conference on, Washington DC.

Murdoch, J. (1998). Does Microfinance Really Help? New Evidence from Flagship Programs in Bangladesh. http://www.nyu.edu/projects. (Accessed on 15/11/09).

Onchan, T. (Ed.) (2004). Non Farm Employment Opportunities in Rural Asia. Asia Productivity Organization, Tokyo

Otero, M. (1999). Bringing Development Back into Microfinance. Journal of Microfinance, 1, 8-19

Parker, J. and Pearce, D. (2001). Microfinance, Grants, and Non -Financial Responses to Poverty Reduction: Where Does Micro credit Fit? Consultative Group to Assist the Poor Focus Note NO. 20. Washington, DC.

Pitt, Mark, Khandker, S. Chowdhury, O. H. and Millimet, D. (2003): "Credit Programs for the Poor and the Health Status of Children in Rural Bangladesh." International Economic Review 44(1):87-118

Priya, M. (2006). The Effects of Microfinance Program Participation on Income and Income Inequality: Evidence from Ghana. http://cniss.wustl.edu/publications (Accessed on 15/11/09).

Pronyk, P., Hargreaves, J., and Murdoch J. (2007). Microfinance Programmes and Better Health: Prospects for Sub Saharan Africa. Journal of American Medical Association, 29(16): 1925-1927

Rogaly, B. (1996). Microfinance Evangelism, Destitute Women, and the hard selling of a New Antipoverty Formula, Development in Practice, 6, 100-112.

Roodman, D. (2009). What do we Really Know about Microfinance? http://blogs.cgdev.org. Accessed on 10/11/09

Rosenberg, R. (1998). Independent Review of UNCDF Microfinance Activities. http://www.uncdf.org (Accessed on 26/11/09). 
Sachs, J. (2009). Is Microfinance the Solution to Poverty? http://www.kiva.org (accessed on 29/11, 09)

Sulaiman, M. and Matin, I. (2002). How beneficial has Microfinance been for the Poorest? Finance for the Poor Volume 1

United Nations Capital Development Fund [UNCDF]. (1999).Microfinance: Building on Lessons Learned. . United Nations, New York.

United Nations Capital Development fund [UNCDF]. (2009). Enabling Poor Rural People to Overcome Poverty in Ghana. United Nations, New York.

Wehrell, R., Campbell, M., Cunningham, G., and Lee, N. (2002). The Atlantic Micro-credit Socio -Economic Impact Study Final Report. Steering Committee to Coordinate Research on Microcredit in Atlantic Canada.

Winkels, R. (2008). Dos and don'ts for microfinance amateurs. www.microfinance. (Accessed on 03/09/09)

World Bank. (2006): Ghana and the World Bank: 50 Years of Reliable Partnership www.worldbank.org/ghana. (Accessed on 29/3/08)

World Factbook. (2008). The Economy of Ghana. CIA, Washington, DC. 